\title{
Analysis of Respiratory Syncytial Virus in Clinical Samples by Reverse Transcriptase-Polymerase Chain Reaction Restriction Mapping
}

\author{
Angel Valdivia ${ }^{+}$, Clara Savón, Danay Chacón, Luis Sarmiento, Luis Morier, \\ Anselmo Otero, Yudira Soto, Suset Oropesa, Angel Goyenechea
}

\author{
Instituto de Medicina Tropical "Pedro Kourí”, Apartado 601, Marianao 13, La Habana, Cuba
}

\begin{abstract}
The aim of this study was to develop a polymerase chain reaction (PCR) for the detection of respiratory syncytial virus (RSV) genomes. The primers were designed from published sequences and selected from conserved regions of the genome encoding for the N protein of subgroups A and B of RSV. PCR was applied to 20 specimens from children admitted to the respiratory ward of "William Soler" Pediatric Hospital in Havana City with a clinical diagnosis of bronchiolitis. The PCR was compared with viral isolation and with an indirect immunofluorescence technique that employs monoclonal antibodies of subgroups $A$ and B. Of 20 nasopharyngeal exudates, 10 were found positive by the three assayed methods. In only two cases, samples that yielded positive RNA-PCR were found negative by indirect immunofluorescence and cell culture. Considering viral isolation as the "gold standard" technique, RNA-PCR had 100\% sensitivity and $80 \%$ specificity. RNA-PCR is a specific and sensitive technique for the detection of the RSV genome. Technical advantages are discussed.
\end{abstract}

Key words: respiratory syncytial virus - polymerase chain reaction - restriction mapping - diagnosis

Respiratory syncytial virus (RSV) is well recognized as the single most important pathogen accounting for acute viral infection of the lower respiratory tract in infants and young children. Outbreaks of RSV infection usually occur during the winter and early spring (Spence \& Barrat 1968, Kim et al. 1973, Mufson et al. 1973, Sung et al. 1987). Rapid detection of RSV is mandatory for early diagnosis, isolation measures, and, if necessary, antiviral therapy. Several rapid diagnostic methods, including the enzyme immunoassay and immunofluorescence, which rely on detection of the RSV antigen in respiratory secretions, have been increasingly used for that purpose (Smith et al. 1991). There are two subgroups, A and B, of RSV. These were originally defined serologically (Anderson et al. 1985, Mufson et al. 1985). The polymerase chain reaction (PCR) has been used for detection of many pathogens and the technique is very sensitive and specific. Many of its applications for the detection of microbiological pathogens have been described (Wright \& WynfordThomas 1990, Stoker 1990), and although it has been shown that the technique can be used for clinical samples, there is lack of prospective clini-

${ }^{+}$Corresponding author. Fax: +53-7-21.5957

Received 29 March 1996

Accepted 22 January 1997 cal evaluations. Recently some groups have carried out reverse transcriptase PCR for the detection of RSV genomes (Paton et al. 1992, Cubie et al. 1992). In the present study, we developed a specific RNA-PCR for RSV, which may be used for diagnostic purposes. The specificity and sensitivity of selected primers were evaluated using the "Long" standard strain and other respiratory viruses.

\section{MATERIALS AND METHODS}

Viruses and cells - The "Long" strain of RSV and strains of parainfluenza 3, adenovirus 3, measles and influenza types A were obtained from the clinical virology laboratory of the Institute of Tropical Medicine "Pedro Kourí". HEp2 two cell line was grown in minimum essential medium (MEM) containing 10\% fetal calf serum, 1\% glutamine, $100 \mathrm{U} / \mathrm{ml}$ penicillin and $100 \mu \mathrm{g} / \mathrm{ml}$ streptomycin sulfate.

Processing of clinical specimens - Twenty nasopharyngeal exudates were obtained from children admitted to the respiratory ward of "William Soler" Pediatric Hospital in Havana City. All samples were suspended in a final volume of $2 \mathrm{ml}$ of MEM containing antibiotics. For PCR analysis, $500 \mu \mathrm{l}$ were used in a $1.5 \mathrm{ml}$ tube, and the samples stored at $-70^{\circ} \mathrm{C}$ until being tested.

Cell culture and indirect immunofluorescence were conducted according to previously reported procedures (Parrott et al. 1979). The diluted speci- 
mens were centrifuged at $2,000 \mathrm{rpm}$ for $10 \mathrm{~min}$ and processed as follows:

Viral isolation - Briefly, two glass tubes covered with monolayers of HEp-2 cells, were inoculated with $0.2 \mathrm{ml}$ of supernatant from each sample. The supernatant from these samples was subcultured three times on HEp-2 cells, until a cytopathic effect (CPE) was observed.

Indirect immunofluorescence assay (IFA) - The infected cells displaying CPE were harvested by scraping each monolayer into $2 \mathrm{ml}$ of MEM and the cells were collected by centrifugation at $2,000 \mathrm{rpm}$ for $10 \mathrm{~min}$ at $4^{\circ} \mathrm{C}$. The cells were washed twice with phosphate buffered saline (PBS), $\mathrm{pH}$ 7.4 , resuspended in PBS to 200,000 cells $/ \mathrm{ml}$ and spotted at 80 cells $/ 250 \times$ microscopic field on 12 well fluorescent antibody slides (Flow Laboratories, McLean, VA).

The slides were allowed to air dry, and the cells were fixed with ice-cold acetone for $10 \mathrm{~min}$. Each slide was previously washed with PBS and drained. The cells were firstly incubated at $37^{\circ} \mathrm{C}$ with the monoclonal antibodies. After $60 \mathrm{~min}$ of incubation at $37^{\circ} \mathrm{C}$, the slides were washed twice with PBS for $5 \mathrm{~min}$ each. The cells were then treated with fluorescein-conjugated goat anti mouse serum (BIOCEN, Cuba) for $60 \mathrm{~min}$, at $37^{\circ} \mathrm{C}$, washed as described above, mounted and viewed with a $25 \mathrm{X}$ oil immersion objective using a fluorescent microscope with epiillumination (Ernst Leitz, Wetzler, West Germany). The monoclonal antibodies were used at a dilution of 1:1000. These monoclonals have identified three types of epitopes in the G molecule (Garcia-Barreno et al. 1989, Garcia et al. 1994): (a) variable epitopes, (b) subgroup specific epitopes, and (c) conserved epitopes, shared by subgroups $\mathrm{A}$ and $\mathrm{B}$. These monoclonals were 021/1G, 021/19G, 021/686G, 021/786G and they were provided by Professor JA Melero, Department of Molecular Biology, National Center of Microbiology, Virology and Sanitary Immunology, Madrid, Spain.

The plaque test assay - It was performed as described by Kisch and Johnson (1963). The nucleic acid extraction, cDNA (reaction) and PCR were performed as described by Cane and Pringle (1991, 1992).

Nucleic acid extraction - All small-scale RNA extractions were carried out in $1.5 \mathrm{ml}$ microfuge tubes. Half a $\mathrm{ml}$ from nasopharyngeal exudate samples were centrifuged in a microfuge for $5 \mathrm{~min}$. The cell pellet was resuspended in $0.5 \mathrm{ml}$ of $3.5 \mathrm{M}$ urea, $200 \mathrm{mM} \mathrm{NaCl}, 10 \mathrm{mM}$ Tris-HCL pH 7.8, 5 $\mathrm{mM}$ EDTA, $0.75 \mathrm{mM} \mathrm{MgCl} 2,0.5 \%$ SDS and $0.35 \%$ NP40. Then $0.5 \mathrm{ml}$ of chloroform-phenol (1:1) (buffered with $150 \mathrm{mM} \mathrm{NaCl}, 10 \mathrm{mM}$ TrisHCL PH 7.8, 1 mM EDTA) was added, the mix- ture vortexed for about $5 \mathrm{sec}$ and centrifuged for $10 \mathrm{~min}$. The aqueous layer was extracted again with phenol-chloroform and then $1 \mathrm{ml}$ of ethanol was added; the nucleic acids were precipitated at $-20^{\circ} \mathrm{C}$ for $20 \mathrm{hr}$, pelleted, washed with $0.5 \mathrm{ml}$ of $70 \%$ ethanol, vacuum-dried and resuspended in $20 \mu \mathrm{l}$ of distilled water.

cDNA reaction - Preparation of cDNA was carried out with approximately 50 ng of RNA (spectrophotometrically quantified) in a $20 \mu \mathrm{l}$ volume containing $100 \mathrm{ng}$ of each primer. The target RNA was mixed with both primers and placed at $65^{\circ} \mathrm{C}$. After $15 \mathrm{~min}$, the solution was placed on ice and the following were added: $100 \mathrm{mM}$ Tris-Hydrochloride, $\mathrm{pH} 8.3 ; 500 \mathrm{mM} \mathrm{KCl} ; 25 \mathrm{mM} \mathrm{MgCl}$; $25 \mathrm{mM}$ (each) dATP, dCTP, dGTP, and dTTP; 20 U RNA sin (Boehringer Mannhein GmbH, Germany) and $5 \mathrm{U}$ of AMV reverse transcriptase (Boehringer Mannhein GmbH, Germany). Incubation was carried out at $42^{\circ} \mathrm{C}$ for $30 \mathrm{~min}$. Finally, the reaction mixture was placed at $95^{\circ} \mathrm{C}$ for $5 \mathrm{~min}$ and kept on ice until the PCR was carried out. The cDNA reaction and the PCR were performed using the recommended strict protocol with all precautions to prevent contamination (Kwok \& Higuchi 1989, Kitchin \& Bootman 1993).

Polymerase chain reaction - PCR mixture was made up to a volume of $100 \mu \mathrm{l}$, containing 100 $\mathrm{mM}$ Tris-hydrochloride; $\mathrm{pH}: 8.3 ; 500 \mathrm{mM} \mathrm{KCl}$; $25 \mathrm{mM} \mathrm{MgCl} 2$; distilled water and $2.5 \mathrm{U}$ of Taq DNA polymerase (Boehringer Mannhein $\mathrm{GmbH}$, Germany). Two drops of mineral oil were added to prevent evaporation. The amplification was carried out in 30 cycles in a Perkin-Elmer Cetus Thermal cycler. Each cycle consisted of denaturation at $93^{\circ} \mathrm{C}$ for $1.5 \mathrm{~min}$, annealing of the primer at $55^{\circ} \mathrm{C}$ for $1.5 \mathrm{~min}$, and chain elongation at $72^{\circ} \mathrm{C}$ for 1.5 min.

Controls - Distilled water, mixed buffer solutions, full-time open vial with final buffer mixture, a nasopharyngeal exudate from an asymptomatic individual and HEp-2 RNA were included as negative controls. RNA from a RSV reference strain ("Long") was prepared as positive control.

Analysis of the amplified products - After the last cycle of amplification, $10 \mu \mathrm{l}$ of the amplified products were analyzed by electrophoresis on $2 \%$ agarose gels with Tris-borate buffer. The remainning of products were diluted with $100 \mu \mathrm{l}$ $\mathrm{H}_{2} \mathrm{O}$, extracted with $150 \mu \mathrm{l}$ phenol-chloroform, and ethanol precipitated and then digested with PstI, HaeIII, HindIII, and Bgl II. These restriction enzymes were chosen with reference to the sequences of the $\mathrm{N}$ protein genes of subgroup $\mathrm{A}$ and B RS viruses (Johnson \& Collins 1989). The correct interpretation and classification of the restriction patterns obtained was performed according 
to previous reports (Cane \& Pringle 1991, 1992). All negative samples were subjected to a second amplification reaction with $1 \mu \mathrm{l}$ of the initial amplification reaction containing all the components described above.

Selection of the primers - The primers originally designed to amplify between nucleotides 858 and 1135 of the human RSV N gene (Collins et al. 1985) have been previously described (Cane \& Pringle 1991), namely:

\section{N1: 5'GGAACAAGTTGTTGAGGTTTATGAATATGC 3' N2: 5'CTTCTGCTGTCAAGTCTAGTACACTGTAGT 3'}

The oligonucleotides were prepared with an applied Biosystems 380B DNA synthesizer and purified by HPLC on reverse phase column.

Comparison of RNA-PCR sensitivity with the plaque test assay and IFI - The "Long" strain was cultured on HEp2 cells in flasks with a surface area of $25 \mathrm{~cm}^{2}$, containing $5 \mathrm{ml}$ of MEM, $5 \%$ fetal calf serum, $1 \%$ glutamine, $100 \mathrm{U} / \mathrm{ml}$ penicillin and 100 $\mu \mathrm{g} / \mathrm{ml}$ streptomycin sulfate. When extensive CPE was present, the cells were detached into the tissue culture medium by shaking with sterile glass beads, then 10-fold serial dilution of this strain were made. Half a $\mathrm{ml}$ of each was put in three different tubes. All tubes were centrifuged at 2,000 rpm. The cell pellet was tested in parallel by plaque test assay, immunofluorescence test and RNA-PCR. PCR products from this experiment were transferred to a nylon membrane (HybondN+, Amershan, Bucks, UK) in a Southern blot experiment (Maniatis et al. 1989) using the same primers as for amplification detection. This experiment was carried out as follows: the reaction was carried out at a final volume of $50 \mu \mathrm{l}$, containing: $100 \mathrm{ng}$ of each primer, $1 \mu \mathrm{l}$ of polynucleotide kinase enzyme $(11 \mathrm{U} / \mu \mathrm{l})$ (Boehringer Mannhein, GmbH, Germany), $5 \mu \mathrm{l}$ of enzyme buffer (10X), and $50 \mathrm{UCi}$ of Gamma $\mathrm{p}^{-32}$ ATP. The volume was completed to $50 \mu \mathrm{l}$ with distilled water. The tube was placed at $37^{\circ} \mathrm{C}$ for $1 \mathrm{hr}$, and afterwards at $80^{\circ} \mathrm{C}$ during $10 \mathrm{~min}$ in order to inactive the enzyme. The marked primers were hybridated with the PCR products transferred by nylon membrane. This was performed to evaluate the ability of the RNA-PCR method over Southern blot.

\section{RESULTS}

Identification of the isolated strains with monoclonal antibodies by IFA - All clinical specimens positive by cell culture were identified to subgroup A.

Specificity of the primer - The specificity of the primer was further tested on isolates of a variety of respiratory viruses. The extracted nucleic acid was subjected to RNA-PCR. Specific amplifica- tion of parainfluenza 3, adenovirus 3, measles and influenza types A were not yielded. We also included one nasopharyngeal exudate from asymptomatic patient (Fig. 1). Twenty clinical samples were tested by the RNA-PCR method, using the selected primers. The products were analyzed by electrophoresis on a $2 \%$ agarose gel. All positive clinical samples by RNA-PCR generated a specific amplified product of $277 \mathrm{bp}$. All positive clinical samples showed a restriction patterns NP4 that belonged to subgroup A thus, these results were similar to those obtained by the antigenic characterization using IFA with monoclonal antibodies.

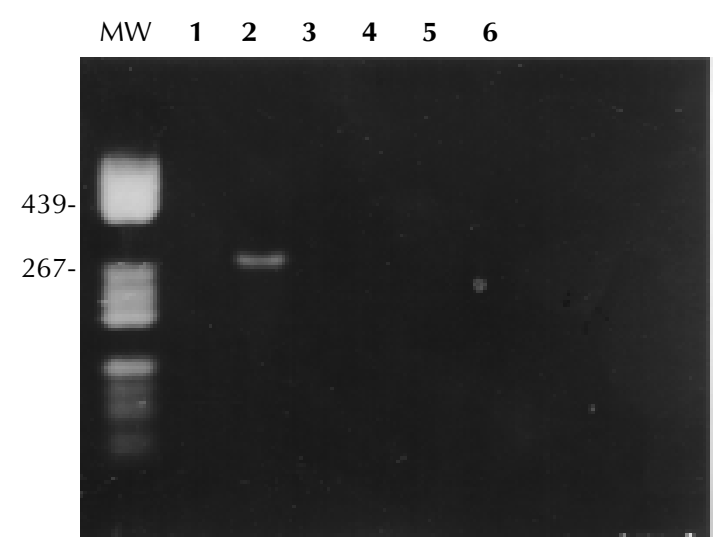

Fig. 1: specificity of the polymerase chain reaction for other respiratory viruses. Position of samples on the gel - 1: nasopharyngeal exudate from an asymptomatic patient. 2: "Long" strain. 3: adenovirus type 3. 4: measles. 5: influenza type A. 6: parainfluenza virus type 3 . The molecular weight of some bands are indicated in base pairs.

Sensitivity - (a) RNA-PCR detected the RSV up to $10^{-4}$ dilution (Fig. $2 \mathrm{a}$ ); (b) the plaque test assay detected RSV up to $10^{-3}$; (c ) the immunofluorescence test detected RSV up to $10^{-3}$ dilution and (d) by the Southern blot analysis the same dilution $\left(10^{-4}\right)$ was detected as by RNA-PCR (Fig. $2 b$ ).

Clinical specimens - The results obtained in the analysis of samples are shown in Table I . Viral isolation was positive in 10 samples; 10 samples were also positive by IFA, and 12 were positive by RNA-PCR. The three tests were in complete agreement in 18 samples, of which 10 were positive $(50 \%)$ and 8 were negative (40\%). Only 2 samples were discordant for the three tests employed. These samples were positive by RNA-PCR and negative by cell culture and the IFA test. The PCR products of these two samples were digested with HindIII and Bgl II and were shown to be specific for RSV (Fig. 3). RNA-PCR sensitivity was $100 \%$ and the specificity was $80 \%$ when compared to virus isolation (Table II). 


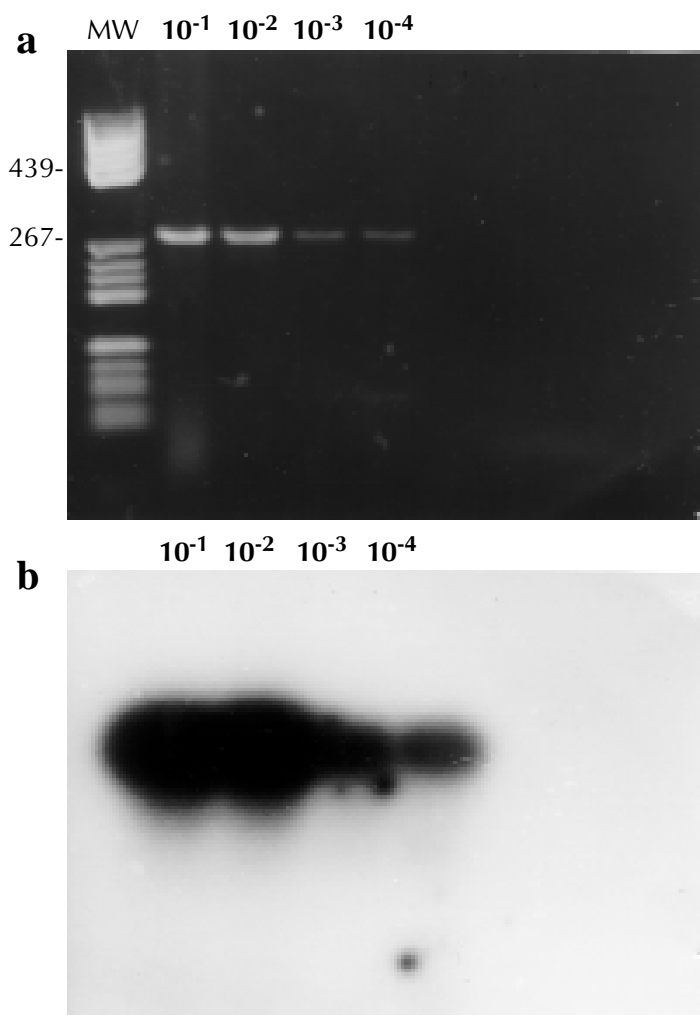

Fig. 2. a: sensitivity of detection of respiratory syncytial virus ("Long" strain) by polymerase chain reaction (PCR). Lane 1 to 4: PCR products from ten fold serial dilution of infected cells. b: gel was blotted to nylon membrane (Hybond-NAmersham) and subsequently analyzed by Southern blot hybridization. The sizes of some PBR 322/Hae III's bands of interest are reflected in base pairs.

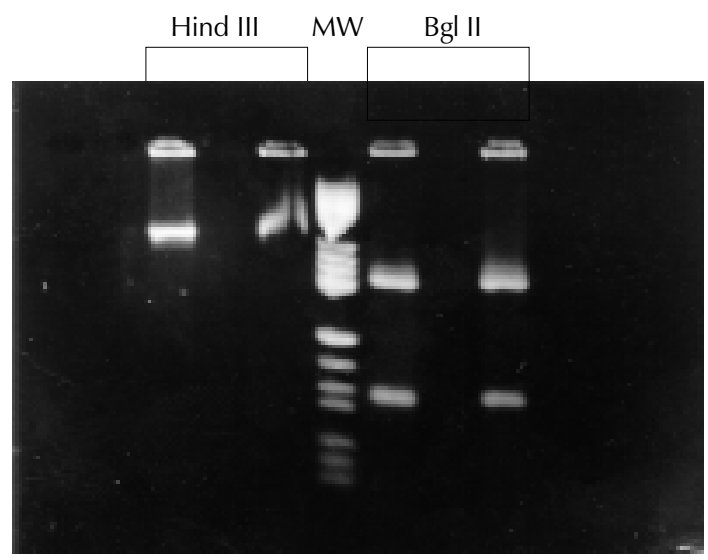

Fig. 3: restriction endonuclease digestion with Hind III (left) and $\mathrm{Bgl} \mathrm{II} \mathrm{(right)} \mathrm{of} \mathrm{amplified} \mathrm{products} \mathrm{from} \mathrm{the} \mathrm{two} \mathrm{positive}$ samples by RNA-polymerase chain reaction and negative by immunofluorescence and cell culture. PBR 322/Hae III is also shown.
TABLE I

Detection of respiratory syncytial virus in clinical samples

\begin{tabular}{lcc}
\hline Techniques & Samples & Positives \\
\hline Viral isolation & 20 & 10 \\
Immunofluorescence & 20 & 10 \\
Polymerase chain reaction & 20 & 12 \\
\hline
\end{tabular}

TABLE II

Comparison of the results obtained by viral isolation, immnufluorescence and polymerase chain reaction

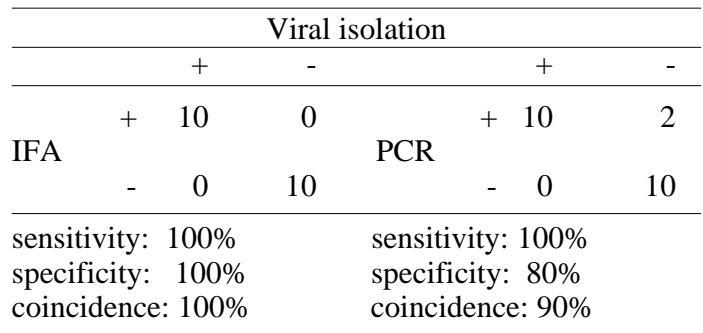

\section{DISCUSSION}

A set of primers, previously used for molecular epidemiology studies (Cane \& Pringle 1991, 1992, Cane et al. 1992), was used for this method. In this work it was demonstrated that the sensitivity for detection of PCR products employing agarose gel electrophoresis with ethidium bromide was similar to the sensitivity obtained with the Southern blot technique. Therefore, we recommend that the Southern blot technique may be used only in cases in which it is necessary to confirm the diagnosis, this will avoid isotopic risk for a reliable diagnosis.

With respect to the identification of RSV, the restriction analysis of PCR products yielded results which were confirmed by the immunofluorescence detection by monoclonal antibodies.

The determination of the sensitivity was carried out by the plaque test. Those dilutions that did not form plaques, were positive by the RNA-PCR.

A good correlation of RNA-PCR with standard cell culture procedure and false positive results in RNA-PCR have been observed by different authors (Paton et al. 1992, Cubie et al. 1992). We found two samples that were positive by RNA-PCR but negative by the culture method, possibly reflecting the presence of some non infectious viral particles in such specimens. These samples were also negative by IFA and positive by RT-PCR. These could be explained because the RT-PCR have higher sensitivity than IFA, thus we consider that these two cases could be false negative results of the cell culture and IFA techniques. 
These findings emphasize the recognized sensitivity of RNA-PCR over conventional methods.

Our study showed that RNA-PCR for the detection of RSV in clinical samples was sufficiently sensitive to allow direct visualization of the resolved PCR product on a 2\% agarose gel without the need for nested amplification or Southern hybridization except to further confirm the identity of amplified products. The ease of the interpretation of PCR results and the ability to perform the test on archival samples are additional advantages. We also proved its feasibility for the diagnosis of RSV, considering that RNA-PCR will provide reliable results in a shorter period (1 versus 28 to 35 days) than the classical isolation procedures. This is of great relevance for monitoring children under specific therapy. If the technique is applied properly, sensitivity and specificity are the major advantages of the PCR for diagnostic purposes.

\section{ACKNOWLEDGEMENTS}

To Dr Robert Shope and Orquidea Biart for critical review of the manuscript, JA Melero for providing the monoclonal antibodies, and Pilar Perez Breña for providing the primers.

\section{REFERENCES}

Anderson LJ, Heirholzer JC, Tsou C, Hendry RM, Fernie BN, Stone Y, Mcintosh K 1985. Antigenic characterization of respiratory syncytial virus strains with monoclonal antibodies. J Infect Dis 151: 626-633.

Cane PA, Pringle CR 1991. Respiratory syncytial virus heterogeneity during and epidemic: analysis by limited nucleotide sequencing (SH gene) and restriction mapping (N gene). J Gen Virol 72: 349-357.

Cane PA, Pringle CR 1992. Molecular epidemiology of respiratory syncytial virus: rapid identification of subgroup A lineages. J Virol Methods 40: 297306.

Cane PA, Matthews DA, Pringle CR 1992. Analysis of relatedness of subgroup A respiratory syncytial viruses isolated worldwide. Virus Research 25: 1522.

Collins PL, Anderson K, Langer SJ, Wertz GW 1985. Correct sequence for the major nuclecapsid protein mRNA of respiratory syncytial virus. Virol 146: 69-77.

Cubie HA, Inglis JM, Leslie EE, Edmunds AT 1992. Detection of respiratory syncytial virus in acute bronchiolitis in infants. J Med Virol 38: 283-287.

Garcia-Barreno B, Palomo C, Peñas C, Delgado T, Perez-Breña P, Melero JA 1989. Marked differences in the antigenic structure of human respiratory syncytial virus $\mathrm{F}$ and $\mathrm{G}$ glycoprotein. J Virol 63: 925932.

Garcia O, Martin M, Dopazo J, Arbiza J, Frabasile S, Russi J, Hortal M, Perez-Breña P, Martinez I, GarciaBarren B, Melero JA 1994. Evolutionary pattern of human respiratory syncytial virus (Subgroup A):
Cocirculating lineages and correlation of genetic and antigenic changes in the $\mathrm{G}$ glycoprotein. $J$ Virol 68: 5448-5459.

Johnson PR, Collins PL 1989. The 1B (NS2), 1C (NS1) and $\mathrm{N}$ proteins of human respiratory syncytial virus (RSV) of antigenic subgroups A and B: sequence conservation and divergence within RSV genomic RNA. J Gen Virol 70: 1539-1547.

Kim HW, Arrobio JO, Brandt CD, Jeffries BC, Pyles G, Reid JL, Chanock RM, Parrot RH 1973. Epidemiology of respiratory syncytial virus in Washington, D.C. Importance of the virus in different respiratory tract disease syndromes and temporal distribution of infection. Am J Epidemiol 98: 216-225.

Kisch AL, Johnson KM 1963. A plaque assay for respiratory syncytial virus. Proc Soc Exp Biol Med 112: 583-589.

Kitchin PA, Bootman JS 1993. Quality control of the polymerase chain reaction. Med Virol 3: 107-114.

Kwok S, Higuchi R 1989. Avoiding falses positives with PCR. Nature 339: 237-238.

Maniatis T, Frisch EF, Sambrook J 1989. Molecular Cloning, p. 9-31. A Laboratory Manual. Cold Spring Harbor Laboratory Press.

Mufson MA, Levine HD, Wash RE, Mocega-Gonzalez HE, Krause HE 1973. Epidemiology of respiratory syncytial virus infection among infants and children in Chicago. Am J Epidemiol 98: 289-300.

Mufson MA, Orvell C, Rafnar B, Norrby E 1985. Two distinct subtypes of human respiratory syncytial virus. J Gen Virol 66: 2111-2124.

Parrot RH, Kim HW, Brandt CD, Beem MO, Richardson L, Gerin JL, Chanock RM 1979. Respiratory syncytial virus, p. 695-708. In EH Lennette \& NJ Schmidt (eds), Diagnostic Procedure for Viral, Rickettsial and Chlamydial Infection. Amer Pub Health Ass, Washington, D.C.

Paton AW, Paton JC, Lawrence AJ, Harris RJ 1992. Rapid detection of respiratory syncytial virus in nasopharyngeal aspirates by reverse transcription and polymerase chain reaction amplification. J Clin Microbiol 30: 901-904.

Smith CM, Creutz C, Huang YT 1991. Detection of respiratory syncytial virus in nasopharyngeal secretions by shell vial technique. J Clin Microbiol 29: 463-465.

Spence L, Barrat N 1968. Respiratory syncytial virus associated with acute respiratory infections in Trinidadian patients. Am J Epidemiol 88: 257 266.

Stoker NG 1990. The polymerase chain reaction and infectious diseases: hopes and realities. Trans $R$ Soc Trop Med Hyg 84: 775-758.

Sung RYT, Murray HGS, Chan RCK, Davies DP, French GL 1987. Seasonal patterns of respiratory syncytial infection in Hong Kong: a preliminar report. $J$ Infect Dis 156: 527-528.

Wright PA, Wynford-Thomas D 1990. The polymerase chain reaction: miracle or mirage? A critical review of its uses and limitations in diagnosis and research. J Pathol 162: 99-117. 
394 RSV in Clinical Samples by RT-PCR - A Valdivia et al. 